Institute of $\mathbf{F}_{\text {ood and }} \mathbf{A}_{\text {gricultural }} \mathbf{S}_{\text {ciences }}$

\title{
A Fruit Fly, Anastrepha ocresia (Walker) (Insecta: Diptea: Tephritide) $)^{1}$
}

H. V. Weems, Jr. ${ }^{2}$

\section{Introduction}

Anastrepha ocresia (Walker) is one of six species of fruit flies of the genus Anastrepha which occur in Florida or which have been established in Florida at some time. This West Indian species has been collected in Florida only in the Keys of Monroe County where it has been found sparingly; it has not been found in Florida since 1936. There is a distinct possibility that this species has not survived in Florida. It is not considered to be of economic importance anywhere within its range.

\section{Synonyms}

Trypeta ocresia Walker

Trypeta tricincta Loew

Acrotoxa ocresia (Walker)

Anastrepha tricincta (Loew)

\section{Distribution}

Florida Keys from Key Largo to Key West, Cuba, Puerto Rico, Jamaica, and Hispaniola. The Florida records are from Rock Harbor, Key Largo Key, July 7, 1936, and from Key West, March 28, 1936. Except for the holotype female (British Museum), the species has not been collected on Jamaica. Other specimens are from the Isle of Pines, the eastern and western tips of Cuba, and Santo Domingo City, Hispaniola. A specimen which subsequently was described by Loew as Trypeta tricincta, a synonym of $A$. ocresia (Walker), was collected aboard ship 60 miles northwest of St. Nicholas, Haiti, but its origin is unknown.

\section{Identification}

Small orange brown fly with patterned wings, banded abdomen, and somewhat long ovipositor sheath. The wing pattern is predominantly dark brown; distal arm of $\mathrm{V}$ band present, separated from proximal arm, or narrowly joined to side of latter at $\mathrm{M}_{1+2}$; proximal arm of $\mathrm{V}$ band usually extending forward to vein $\mathrm{R}_{4+5}$ but not joined to $\mathrm{S}$ band; costal and $\mathrm{S}$ bands connected, the hyaline spot usually not

1. This document is EENY-202 (originally published as DPI Entomology Circular 71), one of a series of Featured Creatures from the Entomology and Nematology Department, Florida Cooperative Extension Service, Institute of Food and Agricultural Sciences, University of Florida. Published: March 2001. This document is also available on Featured Creatures Website at http://creatures.ifas.ufl.edu. Please visit the EDIS Website at http://edis.ifas.ufl.edu and the Entomology and Nematology Department website at http://entnemdept.ifas.ufl.edu/. 2. H. V. Weems, Jr., Florida Department of Agriculture and Consumer Services, Division of Plant Industry, Gainesville, FL.

The Institute of Food and Agricultural Sciences (IFAS) is an Equal Employment Opportunity - Affirmative Action Employer authorized to provide research, educational information and other services only to individuals and institutions that function without regard to race, creed, color, religion, age, disability, sex, sexual orientation, marital status, national origin, political opinions or affiliations. For information on obtaining other extension publications, contact your county Cooperative Extension Service office. Florida Cooperative Extension Service / Institute of Food and Agricultural Sciences / University of Florida / Larry R. Arrington, Interim Dean 


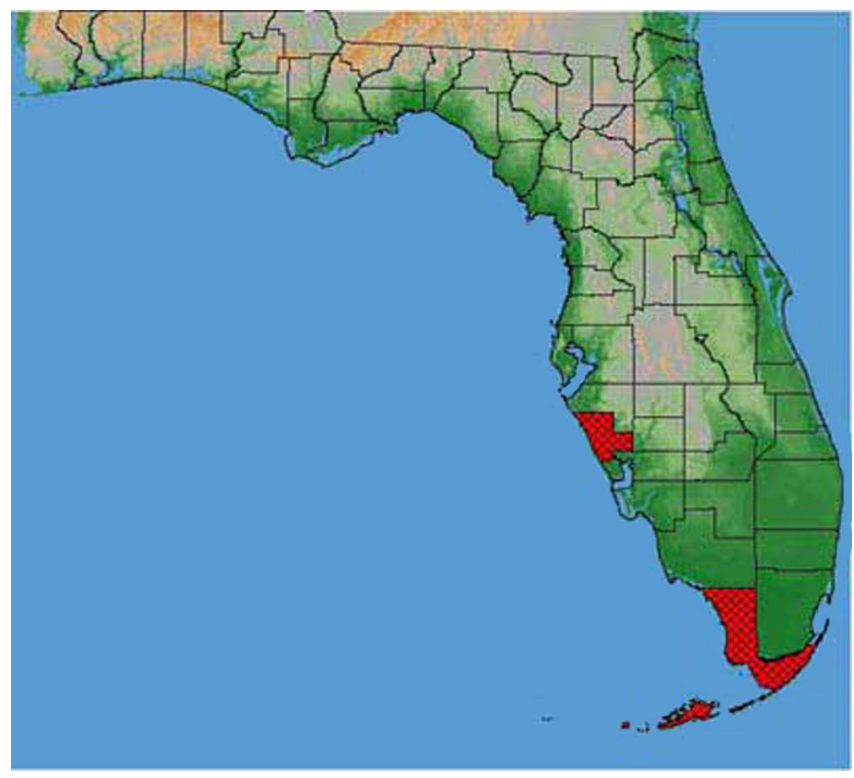

Figure 1. Incidence of Anastrepha obliqua (Walker) in Florida. Credits: G. J. Steck and B. D. Sutton, Division of Plant Industry

touching vein $\mathrm{R}_{4+5}$; wing 6.6 to $7.5 \mathrm{~mm}$ long. Thorax orange brown, with pale- yellow and black markings, black markings consisting of a median spot lying in a brownish band on scutoscutellar suture, acute anteriorly, usually notched posteriorly, and metanotum except for a narrow median stripe.

Macrochaetae black; pile pale yellowish. Abdomen orange brown, with transverse brownish-black bands on tergites 2-4 basally, not reaching lateral margins, and those on tergites 3-4 narrowed or broken medially.

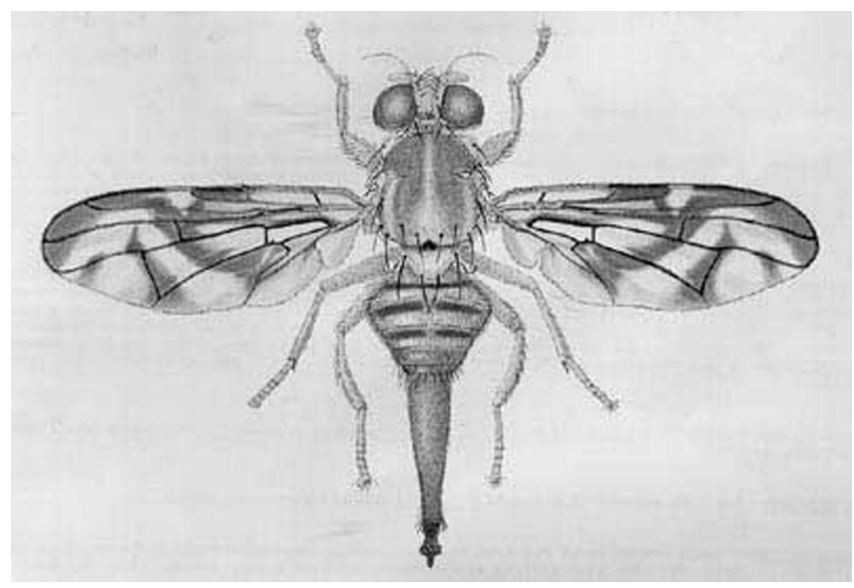

Figure 2. Adult female Anastrepha ocresia (Walker), a fruit fly. Credits: Division of Plant Industry

Ovipositor sheath of female 3.6 to $3.9 \mathrm{~mm}$ long; ovipositor approximately $3.3 \mathrm{~mm}$ long, stout, with many fine, blunt teeth on a little more than posterior half.

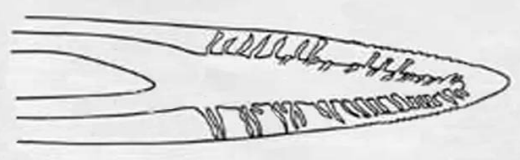

Figure 3. Ovipositor tip of adult female. Credits: Division of Plant Industry

\section{Life History}

The life history of Anastrepha ocresia has not been ascertained.

\section{Hosts}

Reared from Achras zapota (sapodilla), Psidium guajava (common guava); adult female collected on grapefruit.

\section{Selected References}

DaCosta Lima, A. Sept. 1934. Moscas de frutas do genero Anastrepha Schiner, 1868 (Diptera:

Trypetidae). Memorias do Instituto Oswaldo Cruz 28 (4): 487-575.

State Plant Board of Florida Eleventh Biennial Report for the period July 1, 1934-June 30, 1936. Anastrepha tricincta. Jan. 1937. p. 21.

Stone, Alan. 1942. The fruit flies of the genus Anastrepha. USDA Misc. Pub. No. 439. Washington, DC. $112 \mathrm{p}$.

White, I.M., and M.M. Elson-Harris. 1994. Fruit Flies of Economic Significance: Their Identification and Bionomics. CAB International. Oxon, UK. 601 p. 